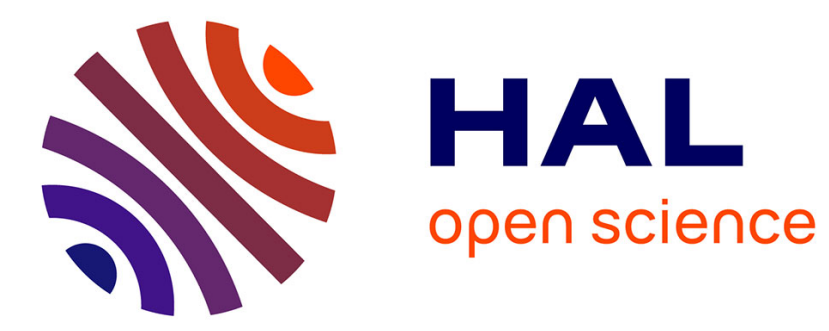

\title{
Basis for designing a tool to evaluate new cultivars
}

Christophe Lecomte, Lorène Prost, Marianne Cerf, Jean-Marc Meynard

\section{To cite this version:}

Christophe Lecomte, Lorène Prost, Marianne Cerf, Jean-Marc Meynard. Basis for designing a tool to evaluate new cultivars. Agronomy for Sustainable Development, 2010, 30 (3), pp.667-677. 10.1051/agro/2009042 . hal-00886474

\section{HAL Id: hal-00886474 https://hal.science/hal-00886474}

Submitted on 1 Jan 2010

HAL is a multi-disciplinary open access archive for the deposit and dissemination of scientific research documents, whether they are published or not. The documents may come from teaching and research institutions in France or abroad, or from public or private research centers.
L'archive ouverte pluridisciplinaire HAL, est destinée au dépôt et à la diffusion de documents scientifiques de niveau recherche, publiés ou non, émanant des établissements d'enseignement et de recherche français ou étrangers, des laboratoires publics ou privés. 


\title{
Basis for designing a tool to evaluate new cultivars
}

\author{
Christophe LeComte ${ }^{*}$, Lorène Prost ${ }^{2}$, Marianne CERF $^{2}$, Jean-Marc MEYNARD 3 \\ ${ }^{1}$ INRA, UMRLEG, 21065 Dijon Cedex, France \\ 2 INRA, UMR 1048 SAD-APT, 78850 Thiverval-Grignon, France \\ ${ }^{3}$ INRA, Département SAD, 78850 Thiverval-Grignon, France
}

(Accepted 1 October 2009)

\begin{abstract}
Seed scientists and decision-makers must evaluate the behaviour of new cultivars. They are thus always seeking improvements in multi-parameter trials. In particular, there is a need for cultivar evaluation tools that include both environmental characterisation of the trials and advanced statistical analysis of genotype by environment interaction. Therefore, in this investigation we gathered agronomists and ergonomists to analyse the functioning, i.e. the activity system, of cultivar evaluation, and to define the specifications of a new tool. We interviewed 21 actors in order to describe and analyse the diversity of evaluation actions such as the objectives of evaluation, criteria to judge cultivars, and configuration of experimentation; and to identify contradictions that appear in the whole activity system to reveal constraints. We deduced the following specifications: (1) to take into account the very short period after harvest in which analyses have to be returned, the tool has to perform automated identification and quantification of environmental constraints in each trial (crop diagnosis) and automated analysis of genotype by environment interaction. (2) The tool has to come up to different actors' expectations concerning environmental or cultivar characterisation or experimental design optimisation. (3) The tool has to be flexible enough to integrate particular knowledge or expertise.
\end{abstract}

cultivar evaluation / genotype by environment interaction / tool design / activity system / crop diagnosis

\section{INTRODUCTION}

In developed countries, plant breeding leads to offering dozens of new cultivars each year. Choosing a cultivar is a key decision for farmers, distributors and processors such as millers as it has a strong effect on (i) harvest volume and quality, (ii) the use of inputs and, as a side effect, (iii) the environmental impact of farming systems. All the actors in the "seed" sector apply evaluation procedures to choose the cultivars that best match their objectives (Meynard and Jeuffroy, 2006). After its creation by breeders, the cultivar is taken over by developers, often at the same company, who work on identifying its most favourable environment of cultivation and market. At roughly the same time, it is submitted to the registration procedures in order to feature in official catalogues, that is a condition for putting it on the market. Then, its seeds are multiplied for sale by multiplication-distribution bodies before being grown and harvested by farmers. Most of the crop is collected by cooperatives that assemble batches for sale. The batches are then processed by food industry firms to form animal and human foodstuffs. The cultivars are evaluated at each

* Corresponding author: christophe.lecomte@ dijon.inra.fr of these stages on national, regional or local scales according to the level at which the actors operate.

The evaluation actors must handle a large mass of information in a short time. The information from experiments must be gathered, verified and processed to reach the objectives of each actor. In the case of wheat in France, the crop cycle runs from October to July and evaluation must then be performed before the start of the next season, hence in August and September. The activity of evaluation is therefore conducted within a constrained framework of time and available data.

Field trials are the main source of information about the behaviour of cultivars. They are generally repeated under different environmental conditions, i.e. varied crop management, and soil and climate conditions to become multi-environment trials (Brancourt-Hulmel et al., 1997; Lecomte, 2005). The evaluation of cultivars by experimentation is complicated by the variability in the results from one environment to another (genotype by environment interaction). The effect of genotypes, of the environment and of interaction can be measured. The "environment" effect has been shown to be preponderant, representing some 50 to $80 \%$ of total variation, with the "year" effect having a particularly marked weight. The effect of genotypes and that of interaction are of a similar 
scale and represent 10 to $25 \%$ of total variation (e.g. see the result for wheat: Brancourt-Hulmel et al., 1999; for pea: Biarnès-Dumoulin et al., 1996; for soya: Desclaux, 1996; and for maize: Epinat-Le Signor et al., 2001). This diversity of cultivar reactions to the characteristics of environments means that the number of trials must be increased to gain an accurate idea of the cultivar performance; but this very soon encounters the problem of the cost of multi-environment trials. Furthermore, the diversity of cultivar responses is still little analysed by actors, as they mainly focus on the averages obtained by the cultivars throughout multi-environment trials. Thus, catalogues of cultivars mainly provide general information (GEVES, 2005) and farmers and technicians lack data on the reaction of cultivars to limiting factors such as nitrogen deficiency, drought and extreme temperatures (Meynard and Jeuffroy, 2006).

Researchers - agronomists and statisticians - have proposed several tools for aiding in the evaluation of cultivars and interpretation of genotype by environment interaction: crop diagnosis on probe genotypes (Desclaux, 1996; Brancourt-Hulmel et al., 1999) makes it possible to identify and quantify the limiting factors of crop production (Meynard and David, 1992; Doré et al., 1997) and has been attempted in whole multi-environment trials with multiple linear regression (Landau et al., 2000; Clermont-Dauphin et al., 2004; David et al., 2005); joint regression (Finlay and Wilkinson, 1963), genotype (Wricke, 1962) or environmental (ParisotBaril, 1992) ecovalence, multiplicative model (Mandel, 1969; Gauch, 1992), factorial regression (Denis, 1980, 1988) and biadditive factorial regression (Denis, 1988; Van Eeuwijk, 1995) as several interesting ways to perform analysis of genotype by environment interaction. Factorial regression appears particularly useful as cultivar reactions are interpreted in terms of tolerance to the limiting factors identified in the environment (Van Eeuwijk et al., 2004). However, very few of these tools are used. We put forward the hypothesis that before designing a new tool or improving existing ones, we have to show how such tools can be integrated in the evaluation actions as performed through the lifetime of a cultivar. By using an interdisciplinary approach combining agronomy and ergonomics, we therefore propose in this article to analyse evaluation actions to deduce some specifications of a tool that would enhance the abilities of actors to interpret the results of their respective multi-environment trials. We use the case of winter wheat (Triticum aestivum L.) in France.

Ergonomic concepts are used to focus the specifications of design on three directions. Firstly, design ergonomists recognised a long time ago that any tool implements a model of both its use and its user (see Béguin's review, 2009). Building stairs, for instance, is based on a model of a valid person. Many designers have integrated this by trying to enlighten users' needs. But very often, the definition of users' needs remains biased because it does not assess the real complexity of the user's action. The challenge is thus to avoid crystallising a model which hampers the user's action and which would prevent the designed tool from being used. Secondly, ergonomists also say that it is never possible to fully anticipate this model of use: the users are ontologically creative in dealing with the intrinsic variability in their working situations (for example, see the studies of crop management tools by Cerf and Meynard, 2006). As a consequence, Béguin (2009), following other authors, emphasises the need for some plasticity of the tool. It should fit a diversity of situations and persons while defining the borders within which the use remains valid and safe. We should therefore define specifications that are plastic enough to allow the users to adapt the tool to their real action. And thirdly, following Engeström (1987) and Seppänen (2002), the design of a new tool may be seen as an opportunity for change or development of a current activity. An activity is a system where different elements interact: the subject (the user), the object of his/her action (cultivar evaluation), the tools he/she uses to reach this object, and the organisation (rules, community of work, division of labour) in which the work takes place. In our case, understanding cultivar evaluation as an activity system means understanding how evaluation actors, belonging to various organisations, construct and use the main tools involved in the evaluation of the cultivars: multi-environment trials (the first tool), procedures to gather the multi-environment trial data (the second tool) and procedures to analyse these data (the third tool). Because of interactions between the elements of the activity system, any change in one of them may make the other ones change. That is why introducing a new tool may lead to a development of the whole activity of cultivar evaluation. For this development to occur, the new tool should help to show and solve some contradictions or tensions within or between the elements of the current activity system (Engeström, 1987). Contradictions manifest themselves through disturbances and ruptures in practitioners' everyday work actions. Their solving is a fruitful potential for change and development (Seppänen, 2002).

To sum up, we used ergonomic concepts to define the specifications of our new tool (i) by focusing on the characterisation of the elements of the activity of cultivar evaluation: the subject, the object and the tools of this activity, and (ii) by characterising the diversity of the objects and the tools among the potential users as well as the contradictions within the activity system. Doing this, we aimed at crystallising a relevant model of use and user, at giving the new tool enough plasticity and at pointing out some contradictions that the new tool should help to solve.

\section{MATERIAL AND METHODS}

\subsection{Survey set-up and procedures}

The data were gathered from actors involved in the design, management and analysis of multi-environment varietal trials, representing the various jobs concerned with evaluation during the lifetime of a cultivar. The actors interviewed were chosen by starting with known persons for each job. This sample base was enriched by the "snowball" method (Blanchet and Gotman, 1992), in which a person interviewed provides the contact details of the next person in accordance with the request "Can you give us the name of a person whom you consider to perform evaluation in a very different manner to yourself?". This principle makes it possible to achieve the greatest 
Table I. Description of the surveyed actors.

\begin{tabular}{|c|c|c|c|c|}
\hline $\begin{array}{l}\text { Actor } \\
\text { code }\end{array}$ & $\begin{array}{l}\text { Type of } \\
\text { company }\end{array}$ & $\begin{array}{l}\text { Scope of } \\
\text { business }\end{array}$ & $\begin{array}{l}\text { Interviewee's } \\
\text { position }\end{array}$ & $\begin{array}{c}\text { Type of } \\
\text { occupation }\end{array}$ \\
\hline \multirow{2}{*}{ S1.1 } & \multirow{2}{*}{ Breeding firm } & \multirow{2}{*}{$\begin{array}{c}\text { National/ } \\
\text { International }\end{array}$} & (1) Breeding manager & (Breeding) \\
\hline & & & (2) Manager of new development unit & (Development) \\
\hline S2.1 & \multirow{3}{*}{ Breeding firm } & \multirow{3}{*}{$\begin{array}{c}\text { National / } \\
\text { International }\end{array}$} & Breeder & (") \\
\hline $\mathrm{S} 2.2$ & & & Director of breeding programmes & (") \\
\hline D2.3 & & & Development manager & (Development) \\
\hline S3.1 & \multirow{2}{*}{ Breeding firm } & \multirow{2}{*}{$\begin{array}{c}\text { National / } \\
\text { International }\end{array}$} & Breeder & (") \\
\hline D3.2 & & & $\begin{array}{l}\text { Development manager (and head } \\
\text { of a network of cooperatives) }\end{array}$ & (") \\
\hline $\mathrm{I} 4.1$ & \multirow{3}{*}{$\begin{array}{c}\text { Body responsible } \\
\text { for registering } \\
\text { cultivars }\end{array}$} & National & Secretary of cereals unit & (Registration) \\
\hline $\mathrm{I} 4.2$ & & National & Managers of wheat (1) and barley (2) MET & (") \\
\hline $\mathrm{I} 4.3$ & & National & $\begin{array}{l}\text { Manager of the oilseeds network and } \\
\text { secretary of the flax unit }\end{array}$ & (") \\
\hline R5.1 & $\begin{array}{c}\text { Organisation of } \\
\text { multipliers - distributors }\end{array}$ & National & $\begin{array}{l}\text { Head of a network of cooperatives } \\
\text { (and development manager with two breeders) }\end{array}$ & (Distribution network) \\
\hline M6.1 & \multirow{2}{*}{ Multiplier - distributor } & Regional & Cultivar manager in the seeds unit & (Multiplication \\
\hline M6.2 & & Regional & Cultivar manager in the technical unit & - distribution) \\
\hline M7.1 & Multi - distrib. & Regional & Cultivar manager in the technical unit & (") \\
\hline M8.1 & Multi - distrib. & Regional & Manager of the agronomics unit & (") \\
\hline M9.1 & \multirow{2}{*}{ Multiplier -. distributor } & Regional & Manager of the technical unit & (") \\
\hline M9.2 & & & Cultivar manager in the technical unit & (") \\
\hline T10.1 & Farmers' organisation & Local & Manager of the organisation & (Technical) \\
\hline T11.1 & $\begin{array}{c}\text { Departmental organisation } \\
\text { of technical bodies }\end{array}$ & Department (in France) & Manager of the organisation & (") \\
\hline $\mathrm{T} 12.1$ & \multirow[t]{2}{*}{ Technical institute } & National & $\begin{array}{l}\text { Manager of the national network } \\
\text { for evaluating cereal cultivars }\end{array}$ & (") \\
\hline 112.2 & & Regional & Regional engineer, in charge of trials & (") \\
\hline V13.1 & Wheat agro-industry & National & Technical manager & (Food processing) \\
\hline
\end{tabular}

differences between interviewees and thus explores the greatest possible diversity. The procedure stops when a fresh interview no longer provides information that is sufficiently original in comparison with all the preceding interviews.

Twenty-one actors (Tab. I) were interviewed. In order to identify how multi-environment trials are built and used, we interviewed the person responsible for decisions concerning cultivars and, should this be somebody different, the person performing the synthesis and interpretation of the experimental results. The evaluation of soft wheat cultivars is a key interest common to all the surveyed actors.

Observing evaluation actions is difficult for reasons of confidentiality (information generated about a cultivar is of economic value) and because of their temporal structure (evaluation is concentrated in a period of several weeks during which the evaluator must work very rapidly and is infrequently available to explain what he/she is doing). We therefore favoured the semi-directed interview approach (Blanchet and Gotman, 1992) and discussion of the written traces produced by the actors during the evaluation process: collection procedures, score notebooks, trial files and analytical tables. The interviews were conducted by a researcher involved in cultivar evaluation. This is an advantage but may also lead to implicit judgements. The interview technique used limits this risk. It is based on asking the person interviewed five main questions (Tab. II). The person is encouraged to give explanations to describe objectives or constraints better that are not clearly explained and that may be linked to context, motivations and issues not initially being taken into account.

\subsection{Analysis of the data}

All the interviews were transcribed then synthesised in tables with rows for individuals and columns for the characteristics of their actions (called traits later on). We described the diversity of the objectives of the evaluation work, these objectives being defined, for a given actor, by combinations of his/her goals and the criteria that he/she uses to judge cultivars and take his/her decisions. We also identified the diversity in 
Table II. The five main questions asked in each interview.

\begin{tabular}{ll}
\hline 1- & What is your role in the firm and what decisions must you take (regarding cultivars)? \\
\hline 2- & Can you describe how this decision is taken and what information you use? \\
\hline 3- & What risks of error seem to you to be the most serious and what do you do to keep them to a minimum? \\
\hline 4- & Can you describe the present multi-environment trials that you organise or use? \\
\hline 5- & How have your organisation, practices and designs evolved? What factors are responsible for this evolution? \\
\hline
\end{tabular}

the way each actor describes the different tools he/she uses, and more specifically the multi-environment trials.

The information was then processed so that each box in the tables (intersection between an individual and a trait) was filled using three marks corresponding to increasing degrees of importance or complexity. We processed these tables using automatic classification methods with the aim of structuring the diversity. Classification was performed using SAS ${ }^{\circledR}$ software (SAS, 1999-2000) with a cluster procedure, based on a matrix of distance between individuals calculated by the frequency of identical replies among the different variables forming our tables. To identify groups, we chose a threshold according to our ability to make sense of the differences among the groups.

\section{RESULTS AND DISCUSSION}

\subsection{The diversity of the objectives of evaluation work}

The objectives of evaluation are defined by the goals of the actors and by the criteria used in judging cultivars that will enable them to fulfil these goals. Each actor mixes and hierarchises four main goals which orient the design of the multienvironment trials (Tab. III): (1) sorting cultivars (this term is explained below), (2) positioning them geographically or in relation to the market, (3) studying them, and (4) disseminating information on the cultivars by establishing communication support and visits.

The first goal (sorting cultivars) mainly deals with eliminating cultivars. It means discarding the cultivars that do not meet predetermined criteria (especially as defined in registration tests) or those with a character barring acceptance. "Sorting" also means choosing the cultivars that may take a market share and form a range of contrasted cultivars. In this case, the main criterion is the productivity of the cultivar (ability to obtain high yield in several places) as compared with an existing cultivar that it could replace.

The second goal (positioning cultivars) also covers two aspects: determining the geographical growing area of the new cultivar and defining its market. Several criteria for judging cultivars can be used: above all, cultivars are compared with benchmarks defined by the firm according to the market or the geographic zone that it covers (what we have called "market" benchmark cultivars). Yield, quality, earliness, response to techniques (e.g. nitrogen fertilisation, sowing date) and other adaptation criteria (tillering capacity, grain weight) are important in judging cultivars.

The third goal (studying the cultivars) means knowing their yield and quality but also assessing their stability (aptitude to have less varying performance among environments than other cultivars) and adaptation (aptitude to provide high performances in specific environments such as late date of sowing, low plant density, low nitrogen supply, shallow soil, etc.). Resistance of cultivars to cold, diseases and lodging are also taken into account in assessing stability. The cultivars are compared mainly with "market" benchmark cultivars defined by each firm and set in earliness and quality categories.

The fourth goal (disseminating information on the cultivars) leans directly on experimentation, as knowledge is often passed on from technicians or advisors to farmers in the field during visits to trials. The visual appearance of the cultivars is then particularly important, and especially comparison of intensity of lodging or diseases and the response of the cultivars to fungicide sprays.

The establishment of automatic classification based on these goals and criteria of evaluation used by the actors ("Groups" column in Tab. III) allows us to distinguish six different objectives: "Registering", "Breeding", "Developing", "Range designing", "Indexing" and "Scoring technological suitability". These are described in Table IV.

Although this classification brings out objectives related to the stages of the life of the cultivar, it also shows that actors can share objectives while having different positions within their firms. Thus, although some breeders have objectives close to those of the persons in charge of registration, others are close to those of developers. This confirms the need to go beyond occupations to grasp better how actors are really involved in evaluation work.

\subsection{The diversity of configuration of experimentation}

We chose the following descriptors to describe the multienvironment trials: (i) number of genotypes studied (total number and number per trial), (ii) number of trials, (iii) homogeneity of varietal lists between trials, (iv) experimental part entrusted to partners and service providers, (v) number of replicates in a trial, and (vi) experimental set-up. Using these descriptors, we identified 39 different trial networks, with the same actor being able to mobilise several networks to attain his/her objectives.

Automatic classification of 39 multi-environment trials revealed 9 types (Tab. V), that we have named the "Registration", "Start of breeding process", "End of breeding process", "Indexing of company's new breeds", "Commercial development", "Seed producers", "Market development indexing", "Technical indexing" and "Milling" multi-environment trials. 
Table III. Actors' announced goals and cultivar evaluation criteria, classified by the SAS cluster procedure (the "Groups" column indicates the results of the classification). Goals: Sort; Pos = position; Stud = study; Com = disseminate. Criteria: Yield; Qual = quality; YRF = yield regularity factors; Earl = earliness; Adap = other adaptive criteria; Tech = response to cultivation techniques; Stab = performance stability; CTPS = use of CTPS (official Permanent Technical Committee for Breeding) markers and criteria; Mark= comparison markers chosen by the company.

\begin{tabular}{|c|c|c|c|c|c|c|c|c|c|c|c|c|c|c|c|c|c|}
\hline & \multicolumn{4}{|c|}{ Goals } & \multicolumn{9}{|c|}{ Criteria } & \multicolumn{4}{|c|}{ Groups } \\
\hline Actors & $\begin{array}{c}\mathbf{1} \\
\text { Sort }\end{array}$ & $\begin{array}{c}2 \\
P o s\end{array}$ & $\begin{array}{c}\mathbf{3} \\
\text { Stud }\end{array}$ & $\begin{array}{c}\mathbf{4} \\
\text { Com }\end{array}$ & $\begin{array}{c}\mathbf{5} \\
\text { Yield }\end{array}$ & $\begin{array}{c}\mathbf{6} \\
\text { Qual }\end{array}$ & $\begin{array}{c}7 \\
Y R F\end{array}$ & $\begin{array}{c}8 \\
\text { Ear }\end{array}$ & $\begin{array}{c}9 \\
\text { Adap }\end{array}$ & $\begin{array}{c}\mathbf{1 0} \\
\text { Tech }\end{array}$ & $\begin{array}{c}\mathbf{1 1} \\
\text { Stab }\end{array}$ & $\begin{array}{c}\mathbf{1 2} \\
\text { CTPS }\end{array}$ & $\begin{array}{c}13 \\
\text { Mark }\end{array}$ & & & & \\
\hline I4.1 & & & & & & & & & & & & & & 1 & 1 & & \\
\hline I4.2 & & & & & & & & & & & & & & 1 & 1 & & \\
\hline I4.3 & & & & & & & & & & & & & & 1 & 1 & & \\
\hline S1.1 & & & & & & & & & & & & & & 1 & 2 & & \\
\hline S3.1 & & & & & & & & & & & & & & 1 & 2 & & \\
\hline S2.1 & & & & & & & & & & & & & & 1 & 2 & & \\
\hline $\mathrm{S} 2.2$ & & & & & & & & & & & & & & 2 & 1 & 1 & 1 \\
\hline D2.3 & & & & & & & & & & & & & & 2 & 1 & 1 & 1 \\
\hline D3.2 & & & & & & & & & & & & & & 2 & 1 & 1 & 2 \\
\hline R5.1 & & & & & & & & & & & & & & 2 & 1 & 1 & 2 \\
\hline M6.2 & & & & & & & & & & & & & & 2 & 1 & 1 & 2 \\
\hline M7.1 & & & & & & & & & & & & & & 2 & 1 & 1 & 2 \\
\hline M9.1 & & & & & & & & & & & & & & 2 & 1 & 1 & 2 \\
\hline M9.2 & & & & & & & & & & & & & & 2 & 1 & 1 & 2 \\
\hline M8.1 & & & & & & & & & & & & & & 2 & 1 & 1 & 2 \\
\hline M6.1 & & & & & & & & & & & & & & 2 & 1 & 1 & 2 \\
\hline T12.1 & & & & & & & & & & & & & & 2 & 1 & 1 & 2 \\
\hline T10.1 & & & & & & & & & & & & & & 2 & $\overline{1}$ & 2 & \\
\hline T11.1 & & & & & & & & & & & & & & 2 & 1 & 2 & \\
\hline T12.2 & & & & & & & & & & & & & & 2 & 1 & 2 & \\
\hline V13.1 & & & & & & & & & & & & & & 2 & 2 & & \\
\hline
\end{tabular}

Key:

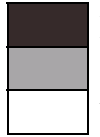

Priority goal Secondary goal Unexpressed goal
Dominant criterion

Criterion mentioned but not dominant Criterion not taken into account
During the life of the cultivar (breeding, registration, indexing, development), a steady decrease in the number of genotypes is observed, correlated with an increase in the number of trials from one year to the next. In the first stages of the life of the cultivars, only small quantities of seed are available, limiting the number of trials and experimental locations. Breeders' experimental designs are complex as they are sought to limit trial sizes while mastering heterogeneous features of the land. For the subsequent large series trials, they are simpler. The demonstration role given to trials by multiplicationdistribution bodies is revealed by a larger number of replicates. One is always left free of fungicide treatment, each plot being positioned in front of a sprayed one of the same cultivar to emphasise the sensitivity of cultivars to diseases. The importance awarded to crop management with no fungicide treatment tends to decrease during the lifetime of cultivars as intensive crop management systems with substantial fungicide spraying are dominant in France. In contrast, cultivar responses to nitrogen fertilisation and sowing density are not studied until after registration. The scale of operation (local, regional or national) of the body commissioning the experimentation also has an influence on the number of trials and homogeneity of cultivar lists. Thus, most actors operating nationally have a greater tendency to delegate their trials, and when the proportion of partnership increases in the conducting of trials, the homogeneity of lists of cultivars decreases. The delegation limits freedom of action for the inclusion of new genotypes in cultivar lists already completed by the partner.

\subsection{The diversity of the ways to perform evaluation deduced from both objectives and configuration of experimentation}

Combining the 6 objectives of evaluation shown in Table IV with the 9 multi-environment trial types in Table $\mathrm{V}$ leads to identifying 11 types of what we have called "evaluation actions": "Registration", "Start of breeding", "End of breeding", 
Table IV. The 6 cultivar evaluation objectives identified and their characteristics, classified by the SAS cluster procedure on the basis of goals and criteria given by actors. $Y R F=$ Yield Regularity Factors; Tech = Sensitivity to techniques; Adap $=$ other adaptation criteria.

\begin{tabular}{|c|c|c|c|c|c|c|c|}
\hline & Objectives & $\begin{array}{l}\text { Cultivar } \\
\text { category } \\
\text { concerned }\end{array}$ & $\begin{array}{l}\text { Priority } \\
\text { goals }\end{array}$ & $\begin{array}{l}\text { Secondary } \\
\text { goals }\end{array}$ & $\begin{array}{l}\text { Dominant } \\
\text { criteria }\end{array}$ & $\begin{array}{l}\text { Secondary } \\
\text { criteria }\end{array}$ & Markers \\
\hline 1 & Registering & New cultivar & Sort & Study & $\begin{array}{c}\text { Yield, } \\
\text { Quality, YRF }\end{array}$ & & CTPS * \\
\hline 2 & Breeding & New cultivar & Sort & $\begin{array}{c}\text { Position } \\
\text { Study } \\
\text { Communicate }\end{array}$ & $\begin{array}{l}\text { Yield, } \\
\text { Quality, } \\
\text { YRF }\end{array}$ & $\begin{array}{c}\text { Earliness, } \\
\text { Adap, Tech, } \\
\text { Stability }\end{array}$ & $\begin{array}{c}\text { CTPS } \\
\text { (Market) }\end{array}$ \\
\hline 3 & Developing & $\begin{array}{l}\text { New cultivar } \\
\text { selected by } \\
\text { the company }\end{array}$ & $\begin{array}{c}\text { Position } \\
\text { Study } \\
\text { Disseminate }\end{array}$ & Sort & $\begin{array}{c}\text { Yield, } \\
\text { Quality, } \\
\text { Adap, Tech }\end{array}$ & $\begin{array}{c}\text { Stability, } \\
\text { YRF }\end{array}$ & $\begin{array}{c}\text { CTPS \& } \\
\text { Market }\end{array}$ \\
\hline 4 & $\begin{array}{c}\text { Range } \\
\text { designing }\end{array}$ & $\begin{array}{l}\text { Registered } \\
\text { cultivars }\end{array}$ & $\begin{array}{c}\text { Study } \\
\text { Disseminate }\end{array}$ & $\begin{array}{c}\text { Sort } \\
\text { Position }\end{array}$ & $\begin{array}{c}\text { Yield, } \\
\text { Quality, } \\
\text { Adap, Tech }\end{array}$ & YRF & $\begin{array}{l}\text { Market } \\
\text { (CTPS) }\end{array}$ \\
\hline 5 & Indexing & $\begin{array}{l}\text { Registered } \\
\text { cultivars }\end{array}$ & $\begin{array}{c}\text { Study } \\
\text { Disseminate }\end{array}$ & Position & $\begin{array}{c}\text { Yield, } \\
\text { Stability }\end{array}$ & $\begin{array}{c}\text { Quality, Adap, } \\
\text { Tech, YRF, } \\
\text { Earliness }\end{array}$ & Market \\
\hline 6 & $\begin{array}{c}\text { Scoring } \\
\text { technological } \\
\text { suitability }\end{array}$ & $\begin{array}{c}\text { Registered } \\
\text { cultivars and } \\
\text { cultivar } \\
\text { combinations }\end{array}$ & Study & Sort & $\begin{array}{c}\text { Quality, Tech, } \\
\text { Stability }\end{array}$ & & Market \\
\hline
\end{tabular}

* CTPS: "Comité Technique Permanent de la Sélection”, official body for registration of new cultivars.

"Development - indexing new breeds", "Commercial development", "Developing a range of seeds", "Market development indexing", "National technical indexing", "Regional technical indexing", "Local market development indexing" and "Milling" (Tab. VI).

Two objectives - "Registering" and "Scoring technological suitability" - correspond to specific multi-environment trials, but the situation is generally more complex. The same objective may be concerned with different multi-environment trials. For example, the objective "Breeding" corresponds to the two actions "Start of breeding process" and "End of breeding process", whose multi-environment trials differ in practically all the descriptive criteria chosen (see Tab. V). The two actions "Regional technical indexing" and "Local market development indexing" also have the same objective (indexing), but each has a multi-environment trial type in common with one of the preceding actions ("Technical indexing" multi-environment trials handled jointly with "National technical indexing" action in the first case and "Market development indexing" multi-environment trials - jointly with "Market development indexing" action in the second). Thus, it is also seen that the same types of multi-environment trials can be used for different objectives.

Actors with large multi-environment trials (registration and national technical indexing networks, corresponding to actions 1 and 8 in Tab. VI) mention their need to optimise these multi-environment trials to reduce costs. They now rationalise the multi-environment trial structure using criteria related to the geographical representativeness of trials and sometimes soil types, but do not truly check the representativeness of the trials against the diversity of agricultural constraints exerted on wheat in France. Many actors in commercial development and technical indexing (evaluation actions 4 to 10) highlight the advantages that would result from diversifying crop management, with some trials under intensive conditions and others conducted on a more extensive basis, or from setting up analytical trials in which all cultivars are tested using different dates or seeding densities. However, this is very rarely done as such a solution comes up against constraints of cost and the shortage of time for processing the results.

\subsection{The diversity of the information collected on trials and of procedures for data analysis}

The interviews reveal great diversity among actors in the information collected (data not shown). However, the following information about genotypes is always evaluated: (i) synthetic variables (yield, baking quality), and (ii) easily collected data: earliness (judged by ear emergence date), and resistance to diseases and to lodging (scores applied to symptoms). Information on the environment is collected to evaluate the representativeness of the trials in relation to the potential cultivation areas of the cultivars, or to be able to identify the less 
Table V. The nine types of multi-environment trials (MET) and their characteristics.

\begin{tabular}{|c|c|c|c|c|c|c|c|}
\hline & Type of MET & $\begin{array}{c}\mathrm{Nb} \text { of trials } \\
\text { (1) }\end{array}$ & $\begin{array}{c}\mathrm{Nb} \text { of } \\
\text { genotypes }\end{array}$ & $\begin{array}{l}\text { Homogeneity } \\
\text { of cultivar } \\
\text { lists }\end{array}$ & $\begin{array}{c}\text { Who conducted } \\
\text { the trial? }\end{array}$ & $\begin{array}{c}\text { Experimental } \\
\text { methods }\end{array}$ & $\begin{array}{c}\mathrm{T} / \mathrm{NT} \\
\text { comparison } \\
\text { (3) }\end{array}$ \\
\hline 1 & $\begin{array}{l}\text { Registration } \\
\text { MET }\end{array}$ & $\begin{array}{c}\text { Average } \\
\text { (1st year) or } \\
\text { high (2nd year) }\end{array}$ & $\begin{array}{l}\text { High (1st year) } \\
\text { or average } \\
\text { (2nd year) }\end{array}$ & Very good & $\begin{array}{l}\text { Subcontractors or } \\
\text { the company, in line } \\
\text { with a contract }\end{array}$ & $\begin{array}{l}\text { Simple (Fisher } \\
\text { blocks, } 2 \text { reps) }\end{array}$ & Systematic \\
\hline 2 & $\begin{array}{c}\text { Start of } \\
\text { breeding } \\
\text { process MET }\end{array}$ & Low & High & Average & $\begin{array}{l}\text { All trials } \\
\text { conducted by } \\
\text { the company }\end{array}$ & $\begin{array}{l}\text { Sophisticated } \\
\text { (lattices...) }\end{array}$ & Frequent \\
\hline 3 & $\begin{array}{c}\text { End of } \\
\text { breeding } \\
\text { process MET }\end{array}$ & Average & Average & $\begin{array}{l}\text { Average } \\
\text { to good }\end{array}$ & $\begin{array}{c}\text { Trials conducted } \\
\text { by the company or } \\
\text { in"close" partnership (4) }\end{array}$ & Variable & Not systematic \\
\hline 4 & $\begin{array}{c}\text { Indexing of } \\
\text { company's new } \\
\text { breeds MET }\end{array}$ & High & Low & Average & $\begin{array}{l}\text { Some trials } \\
\text { conducted by } \\
\text { the company }\end{array}$ & $\begin{array}{c}\text { Simple, } \\
\text { sometimes with } \\
\text { more than } 2 \text { reps }\end{array}$ & Frequent \\
\hline 5 & $\begin{array}{c}\text { Commercial } \\
\text { development } \\
\text { MET } \\
\end{array}$ & High & Low & Heterogeneous & $\begin{array}{c}\text { All trials in } \\
\text { partnership or by } \\
\text { subcontractor }\end{array}$ & $\begin{array}{c}\text { Simple, } \\
\text { sometimes with } \\
\text { more than } 2 \text { reps }\end{array}$ & $\begin{array}{c}\text { Frequent, } \\
\text { often on one } \\
\text { repetition }\end{array}$ \\
\hline 6 & $\begin{array}{c}\text { Seed } \\
\text { producers' } \\
\text { MET }\end{array}$ & $\begin{array}{l}\text { High or } \\
\text { average }\end{array}$ & $\begin{array}{l}\text { High or } \\
\text { average }\end{array}$ & Heterogeneous & $\begin{array}{c}\text { All trials in } \\
\text { partnership or } \\
\text { by subcontractor }\end{array}$ & $\begin{array}{c}\text { Simple, } \\
\text { sometimes with } \\
\text { more than } 2 \text { reps }\end{array}$ & $\begin{array}{l}\text { On at least } \\
\text { part of the } \\
\text { trials }\end{array}$ \\
\hline 7 & $\begin{array}{c}\text { Market } \\
\text { development } \\
\text { indexing } \\
\text { MET }\end{array}$ & $\begin{array}{l}\text { Low or } \\
\text { very low }\end{array}$ & Variable & Good to very good & $\begin{array}{l}\text { All trials } \\
\text { conducted by } \\
\text { the company }\end{array}$ & $\begin{array}{l}\text { Simple, } \\
\text { but with more } \\
\text { than } 2 \text { reps }\end{array}$ & $\begin{array}{l}\text { Not systematic, } \\
\text { on one } \\
\text { repetition }\end{array}$ \\
\hline 8 & $\begin{array}{c}\text { Technical } \\
\text { indexing } \\
\text { MET }\end{array}$ & High & High & $\begin{array}{l}\text { Average or } \\
\text { regional } \\
\text { lists }\end{array}$ & $\begin{array}{l}\text { Trials conducted } \\
\text { by the company } \\
\text { or in "close" } \\
\text { partnership (4) }\end{array}$ & $\begin{array}{l}\text { Sophisticated, } \\
\text { or with more } \\
\text { than } 2 \text { reps }\end{array}$ & $\begin{array}{c}\text { Not } \\
\text { systematic }\end{array}$ \\
\hline 9 & $\begin{array}{l}\text { Milling } \\
\text { MET }\end{array}$ & Low & Low & Heterogeneous & $\begin{array}{c}\text { All trials } \\
\text { conducted by } \\
\text { subcontractors }\end{array}$ & $\begin{array}{c}\text { Subcontractor's } \\
\text { method }\end{array}$ & None \\
\hline
\end{tabular}

(1) Number of trials: low, 2 to 5; high, more than 25.

(2) Number of genotypes: low, less than 10; high, more than 50.

(3) T/NT comparison: treated or non-treated with fungicide comparison.

(4) A "close" partnership is one between companies involved in the same business (e.g. breeding) and which usually cooperate by carrying out some of their trials jointly.

reliable trials, for instance those set up in heterogeneous soils. Environmental data, soil type and previous crop are then always known, contrary to meteorological information, that is not always collected, even the simplest type (rainfall and temperature). Recording information about factors that may have affected yield is frequently performed when trials are visited. It gives overall data to understand why a trial or a cultivar displays unusual behaviour. But it is little instrumented, whereas tools that provide accurate information on environmental factors do exist, such as tensiometers to address water stress. The environmental factors of yield variations are thus almost always addressed intuitively. The type or quantity of information collected is also linked to delegating the conducting of experiments to partners (data not shown).

On the contrary, processing the data yielded by trials shows less diversity. It is often performed in two stages: (1) analysing the results of each trial, and (2) centralising the results by a coordinator, grouping and synthesising all the trials. Analysing each trial generally consists of one-way analysis of variance, followed by a Newman-Keuls test to classify the cultivars into statistical groups. When the multi-environment trials handle a small number of trials, the synthesis can consist of merely reporting side by side the results of the different trials. Most commonly, grouping is performed using the average yield of 
Table VI. 11 types of actions identified as a combination of the 6 types of objectives and the 9 types of multi-environment trials (MET).

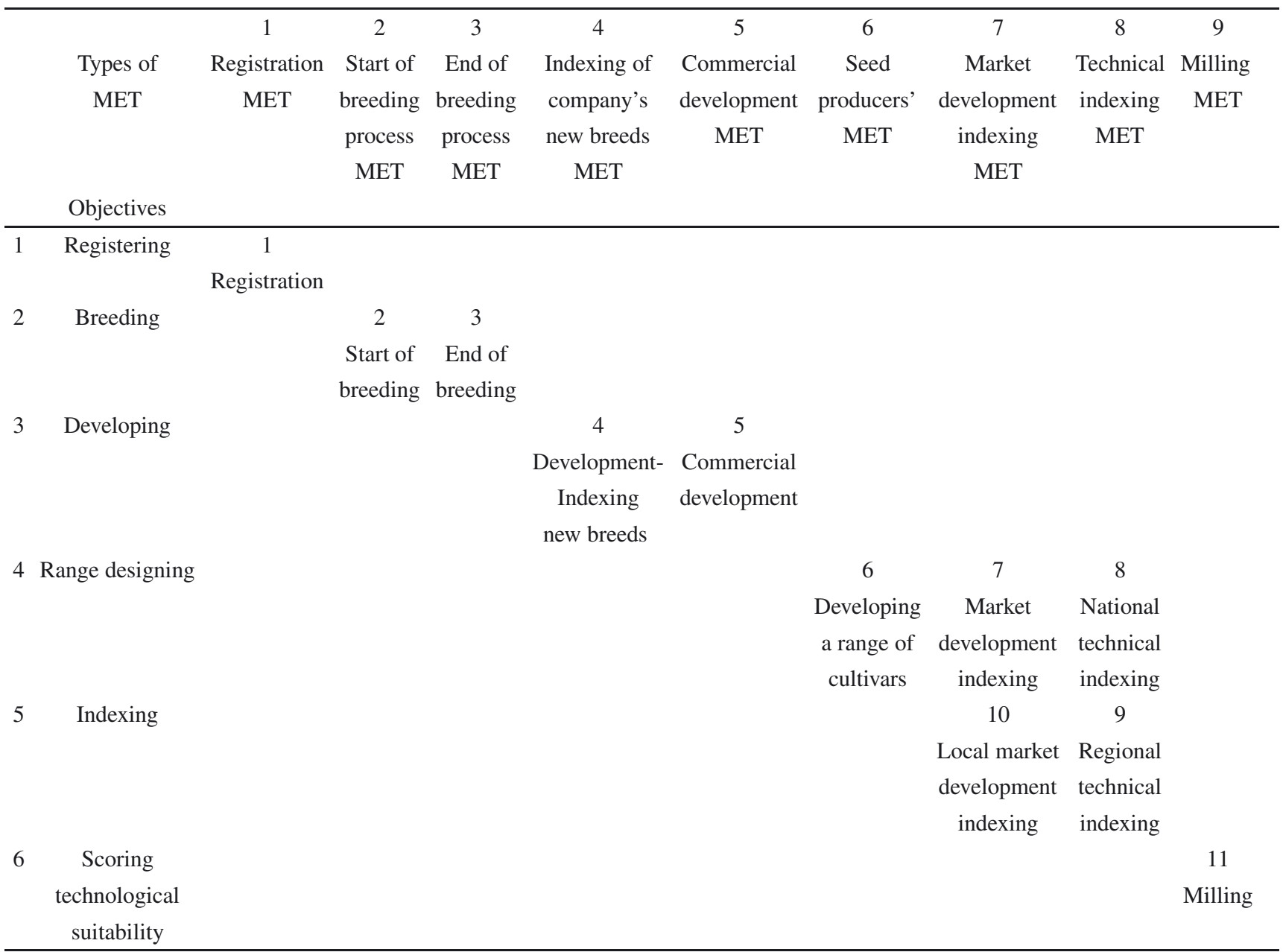

each cultivar in the network, often expressed as a percentage of benchmark cultivars or of the overall average. A few actors present the variability in the results, generally in graph form, or perform an overall analysis of variance. The diversity of methods of analysis and data grouping is small against the strong variability in "evaluation actions". Although all participants in the evaluation of cultivars use ANOVA concepts to attribute the variations in yield to environment, genotype, replicate effect or experimental error, and to assess the accuracy of the tests, they do not use the statistical tools that can break down genotype by environment interaction. However, all admit that it is difficult to account for the variations in genotypes in different environments and that their interpretation resources are limited.

All the actors emphasised that the time available for drawing up syntheses after receipt of the results and before the setting up of the next experiments is very short (only two days for some), necessitating automated data processing procedures. The possibility of returning to the results and deepening analyses during slack periods is more variable, but this is only envisaged by actors who wish to study the results over a period of several years or refine regional groupings of trials.

To a certain extent, the diversity we point out in information collected and data analysis procedures seems to depend greatly on organisational features, which we did not thoroughly study.

\subsection{Contradictions within the activity system}

Actors might build the various tools they use for a given action in a systemic way. Do actors experience this systemic dimension and build coherence between their tools, e.g. configuring experimentation (the multi-environment trials), gathering information (the protocol) and processing this information (statistical tools among others) or do they experience tensions and problems while using their various tools in order to reach their objectives? The issue is that of defining the specifications of a cultivar evaluation support tool that could enable actors to overcome these tensions and the contradictions which are therefore revealed in the activity system. 


\subsubsection{Contradictions between the objectives and the tools}

Comparison of the objectives of the evaluation (Sect. 3.1) with the information collected in the trials (Sect. 3.4) shows that the actors are not always able to access the criteria that they seek. Although there is no difficulty in going from the information gathered to the criteria (GEVES, 2005) for certain traits (earliness, resistance to lodging or to fungal diseases), this is not the case for yield stability or other criteria of adaptation to the environment. As a result, the actors whose objectives are 'Developing' or 'Range designing' say that they would like to characterise cultivar tolerance to drought or to nitrogen stress or their adaptation to a particular soil type, but admit that they are unable to do this properly. Likewise, assessing the 'performance stability' criterion from the yield observed in the trials is not easy with the data analysis performed. Indeed, most actors only use yield data to characterise the average performance of each genotype. We can therefore see here that there is a systemic contradiction between the objective (especially the criteria that define it) and the tools formed by the observation protocols and data analysis methods. Statistical tools do exist that could achieve a better match between configurations and data processing (Brancourt-Hulmel et al., 1997), but actors mention lack of competence in statistics. We also suggest that the actors generally consider multi-environment trials to be a juxtaposition of different experimental situations and not a complex structure, a network. Therefore, it would be useful to have a tool for analysing data on a multi-environment trial scale, using the diversity of the agronomic conditions examined to help actors to overcome these difficulties. Analysis of genotype by environment interaction over the whole multienvironment trial would thus enhance the characterisation of the criteria addressed by the actors, that is to say - depending on the case - tolerance to the various limiting factors or the stability of performance.

Almost all actors wonder about the optimisation of their experimental networks. Those who favour "Market development indexing" and "Commercial development" objectives (evaluation actions 5, 7 and 10 in Tab. VI) are exceptions, as the placing of trials is mainly dictated by the goal "disseminate information". They want to know how they can identify situations that favour the revealing of stability qualities in cultivars or how they can know if certain experimental situations are redundant. These questions reveal a contradiction within the activity system, between (i) the wish to enrich knowledge of the cultivars through a diversity of agronomic situations, (ii) the tools used (multi-environment trials and protocol) that are inadequate for acquiring this knowledge, and (iii) organisation (the problem of the cost and of delegating trials). The facility to design could help actors to seek ways of overcoming this contradiction by proposing a multi-environment trial analysis task that shows the diversity of agronomic conditions explored. This description of diversity would help to optimise the multi-environment trials by making it possible for actors to (i) check that the range of agronomic conditions they are exploring are indeed those they wish to expose the cultivars to and (ii) identify any redundancy between trials.

\subsubsection{Contradictions between the tools}

Some actors regret that interpretation of varietal behaviour is based mainly on subjective impressions and would like to use more objective data. The information gathered about environments generally depends on the configuration of the multi-environment trials. In particular, actors collect smaller amounts of detailed information when they work with a large number of trials that are conducted to a great extent by partners or service providers. However, although many actors consider that better quantification of the characteristics of the environment is possible by using easily available data, e.g. by purchasing meteorological data from national services, they are not very well equipped with regard to the use of these data.

Often transmitted during visits to trials, expertise concerning cultivars is not very formalised. Breeders have the feeling that they know their cultivars well but find it difficult to pass on this knowledge, whereas developers consider that the message they receive from breeders is markedly inadequate and they need to build up their own expertise. The actors whose job is to synthesise and present the knowledge gained about cultivars (e.g. indexing staff) have a particularly acute feeling of the difficulty of assembling and presenting reliable knowledge that takes genotype instability into account. A cultivar evaluation support tool enabling actors to use and formalise their expertise would therefore be much appreciated. The procedure for the analysis of genotype by environment interaction must be sufficiently transparent and accessible for them to be able to enter information resulting from this expertise or to compare data resulting from analysis with their own observations.

\section{CONCLUSION}

Analysis of the diversity of cultivar evaluation actions and of the contradictions within the activity systems has led us to identify two major functions for a tool for aid in the experimental evaluation of cultivars: (i) characterising genotype by environment interactions and knowing the way in which cultivars react to certain limiting factors, and (ii) optimising the size and layout of networks. But according to the diversity of evaluation actions identified, emphasis on these two functions is not the same. Therefore, a new tool aimed at analysing the results of multi-environment trials has to come up to different actors' expectations concerning environmental or cultivar characterisation or experimental design optimisation.

Additionally, the important role of expertise in evaluation activity and the diversity of actions favour leaving a number of choices to actors while they process the results. One actor will wish to incorporate his own expertise, for example, by adding an observation made during visits to trials. Another might wish to adjust the grouping of trials according to the capacity of the groups to separate major types of agronomic constraints. The facility must therefore be able to do all this at the same time, but possibly with differentiated access to the various functions.

Furthermore, working on a multi-environment trial scale inevitably leads to handling large amounts of information. The general constraint of time available for data analysis and the 
lack of mastery of methods to interpret instability on the scale of multi-environment trials lead us to propose a method that could be automated. Finally, evaluation of cultivars in absolute terms must be possible in some actions while, in others, cultivars are evaluated on a relative basis by comparison with benchmark cultivars.

As a consequence, we propose a model which could be viewed as a response to some of these key specifications. Implementation in a prototype called DIAGVAR is being carried out along with the remaining specifications, e.g. (i) automation, (ii) leaving users grouping their trials as they want, and (iii) giving them access to indicators so that they can compare with their own experience for a given trial. The model is based on the combination of (i) agronomic diagnosis using a multiple linear regression on the whole multi-environment trial, aimed at characterising each trial environment by a list of the limiting factors to which the crop is exposed and (ii) a break-down of the genotype by environment interaction with a factorial regression to interpret cultivar reactions in terms of tolerance to the limiting factors. To avoid an increase in the amount of data to be collected, data on environments and on criteria that may have affected yield is limited to a few probe genotypes that would thus be indicators of the limiting factors that appear in the multi-environment trials. Once this procedure has made it possible to identify the limiting factors of the multienvironment trials, it is also possible to see which factors are present in a given environment and their intensity. An environment classification can then be drawn up using the variables describing these limiting factors. We propose to verify in another study that the resulting classification of environments is more effective to identify redundant or missing environments than that performed using classic criteria such as year, geographic zone or crop management.

Although our proposals would doubtless not handle all the contradictions identified in our analysis and do not include discussion of organisational constraints, they lead to a tool which is capable of clearing critical contradictions within the activity system. The development of a prototype based on the lines proposed allowed us to start a second phase of work with some actors to assess the matching of the proposals to the diversity of their evaluation actions (Prost, 2008).

\section{REFERENCES}

Béguin P. (2009) L'ergonomie en conception : cristallisation, plasticité, développement, in: Weil B., Hatchuel A. (Eds.), Les nouveaux régimes de la conception, Paris: Vuibert.

Biarnès-Dumoulin V., Denis J.-B., Lejeune-Hénaut I., Etévé G. (1996) Interpreting yield instability in pea using genotypic and environmental covariates, Crop Sci. 36, 115-120.

Blanchet A., Gotman A. (1992) L'enquête et ses méthodes : l'entretien, Nathan Université Sociologie, Collection 128, Paris.

Brancourt-Hulmel M., Biarnès-Dumoulin V., Denis J.-B. (1997) Points de repère dans l'analyse de la stabilité et de l'interaction génotypemilieu en amélioration des plantes, Agronomie 17, 219-246.
Brancourt-Hulmel M., Lecomte C., Meynard J.-M. (1999) A Diagnosis of Yield-Limiting Factors on Probe Genotypes for Characterizing Environments in Winter Wheat Trials, Crop Sci. 39, 1798-1808.

Cerf M., Meynard J.-M. (2006) Les outils de pilotage des cultures : diversité de leurs usages et enseignements pour leur conception, Natures, Sciences, Sociétés 14, 16-29.

Clermont-Dauphin C., Cabidoche Y.-M., Meynard J.-M. (2004) Diagnosis on low-input cropping systems in a tropical upland of Southern Haiti, Agr. Ecosys. Environ. 105, 221-234.

David C., Jeuffroy M.-H., Henning J., Meynard J.-M. (2005) Yield variation of organic winter wheat: a diagnostic study in the Southeast of France, Agronomie 25, 213-223.

Denis J.-B. (1980) Analyse de régression factorielle, Biométrie Praximétrie 20, 1-34.

Denis J.-B. (1988) Two way analysis using covariates, Statistics 19, $123-132$.

Desclaux D. (1996) De l'intérêt de génotypes révélateurs de facteurs limitants dans l'analyse des interactions génotype milieu chez le soja (Glycine max. L. Merill), Thèse de doctorat, Institut national polytechnique de Toulouse, Toulouse, France, 227 p.

Doré T., Sebillotte M., Meynard J.-M. (1997) A diagnostic method for assessing regional variations in crop yields, Agr. Syst. 54, 169-188.

Engeström Y. (1987) Learning by expanding: An activity-theoretical approach to developmental research, Orienta-Konsultit, Helsinki.

Epinat-Le Signor C., Dousse S., Lorgeou J., Denis J.-B., Bonhomme R., Carolo P., Charcosset A. (2001) Interpretation of Genotype Environment Interactions for Early Maize Hybrids over 12 Years, Crop Sci. 41, 663-669.

Finlay K.-W., Wilkinson G.-N. (1963) The analysis of adaptation in a plant-breeding program, Aust. J. Agr. Res. 14, 742-754.

Gauch H.-G. (1992) Statistical analysis of regional yield trials: AMMI analysis of factorial designs, Elsevier, Amsterdam.

GEVES (2005) Les variétés de Céréales du Catalogue Officiel français, Valeur Agronomique et Technologique des variétés de la liste A, $\mathrm{n}^{\circ} 4$ - juillet 2005, $397 \mathrm{p}$.

Landau S., Mitchell R.-A.-C., Barnett V., Colls J.-J., Craignon J., Payne R.-W. (2000) A parsimonious, multiple regression model of wheat yield response to environment, Agr. Forest Meteorol. 101, 151-166.

Lecomte C. (2005) L'évaluation expérimentale des innovations variétales, Proposition d'outils d'analyse de l'interaction génotype - milieu adaptés à la diversité des besoins et des contraintes des acteurs de la filière semences, Thèse de doctorat, INA P-G, Paris, France.

Mandel J. (1969) The partitioning of interaction in analysis of variance, J. Res. Nat. Bureau of Standards B. Mathematical Sciences 73B, 309-328.

Meynard J.-M., David G. (1992) Diagnostic sur l'élaboration du rendement des cultures. Cah. Agr. 1, 9-19.

Meynard J.-M., Jeuffroy M.-H. (2006) Quel progrès génétique pour une agriculture durable ? in: Quelles variétés et semences pour des agricultures paysannes durables ? Les dossiers de l'Environnement, INRA, Paris 30, 15-25. 
Parisot-Baril C. (1992) Étude de la stabilité du rendement chez le blé tendre d'hiver (Triticum aestivum L. Thell.), Thèse de Doctorat de l'Université Paris-Sud, 210 p.

Prost L. (2008) Modéliser en agronomie et concevoir des outils en interaction avec de futurs utilisateurs : le cas de la modélisation et de l'outil DIAGVAR, Thèse de doctorat, AgroParisTech, Paris, France.

SAS $^{\circledR}$ System, Release 8.01.01 (1999-2000) SAS ${ }^{\circledR}$ Institute Inc., Cary, NC, USA.

Seppänen L. (2002) Creating tools for farmers' learning: an application of developmental work research, Agr. Syst. 73, 129-145.
Van Eeuwijk F.-A. (1995) Linear and bilinear models for the analysis of multi-environment trials: I. An inventory of models, Euphytica 84, $1-7$.

Van Eeuwijk F.-A., Malosetti M., Yin X., Struik P.-C., Stam P. (2004) Modelling differential phenotypic expression, in: New discussions for a diverse planet, Proceedings of the 4th International Crop Science Congress, 26 Sept.-1 Oct. 2004, Brisbane.

Wricke G. (von) (1962) Über eine Methode zur Erfassung der ökologischen Streubreite in Feldversuchen, Z. Pflanzenzücht 47, 92-96. 